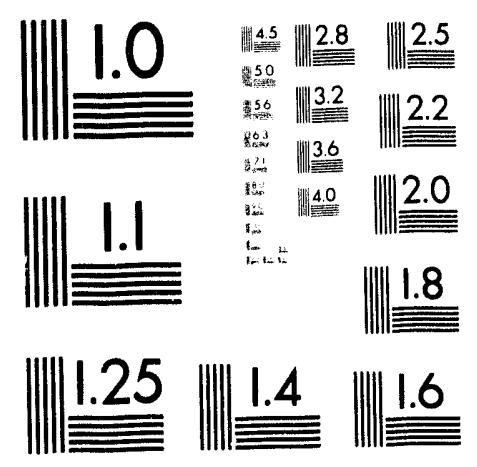



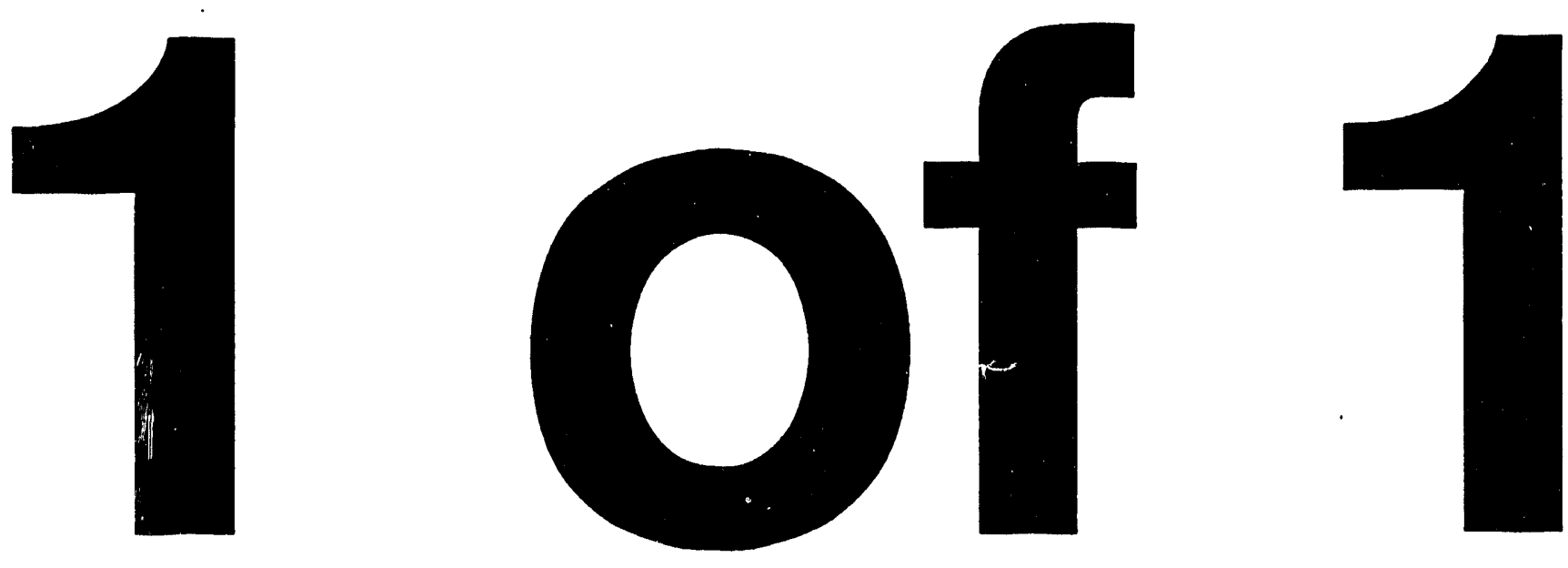
ES/ER/TM-92

\title{
Environmental Restoration Program Pollution Prevention Checklist Guide for the Evaluation of Alternatives Project Phase
}

\author{
Environmental Restoration Division \\ P.O. Box 2003 \\ Oak Ridge, Tennessee 37831-7298
}

Date Issued-September 1993

\begin{abstract}
Prepared for
U.S. Department of Energy

Office of Environmental Restoration and Waste Management under budget and reporting code EW 20

MARTIN MARIETTA ENERGY SYSTEMS, INC. managing the

Oak Ridge K-25 Site Oak Ridge Y-12 Plant

for the

Paducah Gaseous Diffusion Plant Portsmouth Gaseous Diffusion Plant under contract DE-AC05-76OR00001

U.S. DEPARTMENT OF ENERGY
\end{abstract} Oak Ridge National Laboratory under contract DE-AC05-84OR21400 


\section{CONTENTS}

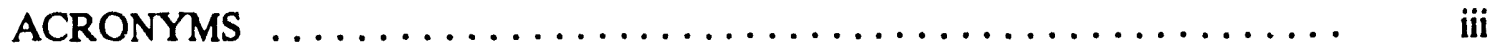

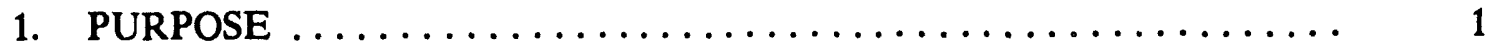

2. APPLICABILITY $\ldots \ldots \ldots \ldots \ldots \ldots \ldots \ldots \ldots \ldots \ldots \ldots \ldots \ldots \ldots \ldots \ldots \ldots$

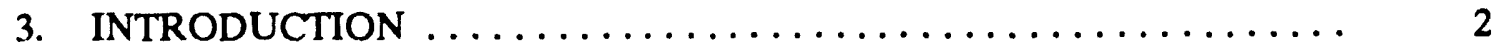

4. USE OF THIS CHECKLIST GUIDE FOR THE EV

PROJECT PHASE ........................ 2

5. INSTRUCTIONS FOR EV PROJECT PHASE USERS

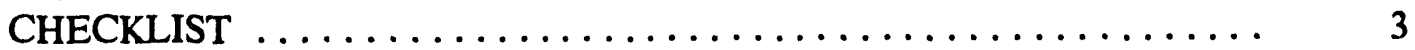

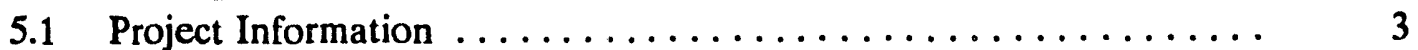

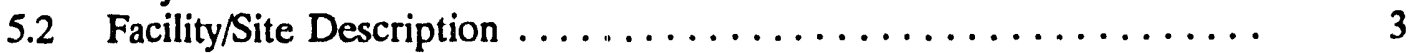

5.3 General Question Information .................... 3

5.4 EV Phase-Specific Question Information ............... 3

5.5 Waste Stream Information $\ldots \ldots \ldots \ldots \ldots \ldots \ldots \ldots \ldots \ldots \ldots$

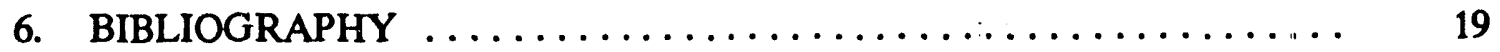

Figure 1 EV Project Phase Checklist $\ldots \ldots \ldots \ldots \ldots \ldots \ldots \ldots \ldots \ldots \ldots \ldots \ldots$

Figure 2 Example Waste Stream Information $\ldots \ldots \ldots \ldots \ldots \ldots \ldots \ldots \ldots \ldots$

Table 1 Summary of Contaminant Material

Disposition Technology for Gaseous

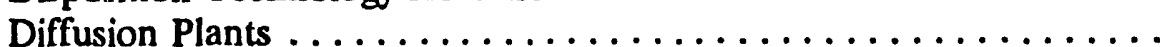




\section{ACRONYMS}

$\begin{array}{ll}\text { CAA } & \begin{array}{l}\text { Clean Air Act } \\ \text { Comprehensive Environnmental Response, Compensation, } \\ \text { and Liability Act } \\ \text { decontamination and decommissioning }\end{array} \\ \text { D\&D } & \text { U.S. Environmental Protection Agency } \\ \text { EPA } & \text { Environmental Restoration } \\ \text { ER } & \text { evaluation of alternatives } \\ \text { EV } & \text { Hazardous Waste Operations } \\ \text { HAZWOPER } & \text { low-level waste } \\ \text { LLW } & \text { National Pollutant Discharge Elimination System } \\ \text { NPDES } & \text { Occupational Safety and Health Administration } \\ \text { OSHA } & \text { polychlorinated biphenyl } \\ \text { PCB } & \text { pollution prevention/waste minimization } \\ \text { PP/WM } & \text { quality assurance } \\ \text { QA } & \text { Resource Conservation and Recovery Act } \\ \text { RCRA } & \text { Superfund Amendments and Reauthorization Act } \\ \text { SARA } & \text { transuranic } \\ \text { TRU } & \end{array}$




\section{PURPOSE}

Evaluation of alternative studies determine what decontamination and decommissioning (D\&D) alternatives are presented to regulators for facility and site cleanup. A key consideration in this process is the waste to be generated. Minimizing the volume and toxicity of this waste will ultimately contribute to the selection of the best clean-up option.

The purpose of this checklist guide is to assist the user with incorporating pollution prevention/waste minimization (PP/WM) in all Evaluation of Alternatives (EV) phase projects of the Environmental Restoration (ER) Program. This guide will assist users with documenting PP/WM activities for technology transfer and reporting requirements. Automated computer screens will be created from the checklist data to help users implement and evaluate waste reduction. Users can then establish numerical performance measures to measure progress in planning, training, self-assessments, field implementation, documentation, and technology transfer. Cost savings result as users train and assess themselves, eliminating expensive process waste assessments and audit teams.

\section{APPLICABILITY}

This checklist guide applies to all ER Program participants performing EV phase projects for all sources of pollution including air emissions, water, and solid waste. This guide is intended to serve three primary audiences:

- Site project managers and others on the project team engaged in activities focusing on or ultimately serving the process of incorporating PP/WM in the EV phase project;

- ER PP/WM specialists-for use as a general overview to help ensure that PP/WM criteria are being applied whenever possible in all EV phase projects; and

- ER Technology Development and Application specialists-for use as a tool for providing new and effective technology information to the site project managers.

Although this checklist guide may be used by a number of individuals as indicated above, it is incumbent on the ER Program to ensure that the projects select and apply technologies that not only result in the smallest quantities of waste with the least toxicity, but also minimize environmental releases during remediation. Minimizing waste generation should be considered along with the capital, maintenance, and operating costs to implement liabilities and any potential threat to human health and the environment. 


\section{INTRODUCTION}

ER activities differ significantly from routine production facilities. While the focus for $\mathrm{PP} / \mathrm{WM}$ for production operations is often on source reduction and recycling, those techniques are not readily adaptable to ER projects. Opportunities for source reduction and recycling are limited for clean-up activities since ER inherits contaminated waste sites from previous production processes, where ongoing process operations generally do not exist. Although treatment is not a preferred alternative per the U.S. Environmental Protection Agency (EPA) hierarchy, the nature of ER activities is generally such that clean up of the site by the application of some treatment technology is often the only alternative. The fact that the waste exists cannot be changed.

The greatest impact on the minimization of waste from the standpoint of the overall ER Program would be the selection of the clean-up option for remediation at a site. The EV phase will generate the alternatives from which the selection of the best clean-up option will be determined.

The success of incorporating PP/WM in the EV phase project will be determined ultimately on how well the volume and toxicity of the waste generated are minimized. However, the evaluation of options and selection of the most appropriate treatment technology for a facility/site (when treatment is deemed appropriate) can be a fairly complex undertaking when the many variables and issues during the remedy selection process are considered. This guide will be useful during the process of how PP/WM is incorporated when treatment technologies are evaluated. Therefore, all efforts contributing to the selection of the best clean-up option and treatment technology will effectively achieve the objcctives of PP/WM.

\section{USE OF THIS CHECKLIST GUIDE FOR THE EV PROJECT PHASE}

The document guide is organized in three sections. The first section of the checklist guide contains general questions about the generator's general pollution prevention program. The second section of the checklist guide entails questions concerning the pollution prevention program as it applies to the EV phase. The third section of the guide is more waste stream specific and contains questions concerning contaminants and media. The generator is also asked to give their rationale on their evaluation of applicable technologies analysis and how they would incorporate pollution prevention. 


\section{INSTRUCTIONS FOR EV PROJECT PHASE USERS CHECKLIST}

The following are the steps used to simplify this guide.

\subsection{PROJECT INFORMATION}

Complete the project information as requested in Sect. 1 of the EV Project Phase Checklist (Fig. 1, p. 4).

\subsection{FACILITY/SITE DESCRIPTION}

Complete the facility/site description as requested in Sect. 1 of the EV Project Phase Checklist (Fig. 1). Provide attachments if necessary.

\subsection{GENERAL QUESTION INFORMATION}

Complete the general questions as requested in Sect. 1 of the EV Project Phase Checklist (Fig. 1).

\subsection{EV PHASE-SPECIFIC QUESTION INFORMATION}

Complete the EV phase-specific questions shown in Sect. 2 of the EV Project Phase Checklist (Fig. 1).

\subsection{WASTE STREAM INFORMATION}

Refer to the Example Waste Stream Information (Fig. 2, p. 13). Then complete the waste stream information as requested in Sect. 3 of the EV Project Phase Checklist (Fig. 1). For additional details on D\&D technologies, refer to the Oak Ridge K-25 Site Technology Logic Diagram document located at the Information Resource Center, Oak Ridge, Tennessee. 
SECTION 1. GENERAL QUESTION INFORMATION

Project Name:

Phase: EV
Project Manager:

Project Location:

Facility/Site Description:

YES NO

1. Is there a PP/WM Site Plan on site?

2. Have those who report to management been trained in:

- Site general employee radiation training?

- 24-hr SARA/OSHA (HAZWOPER) with 8-hr annual refresher?

- RCRA hazardous waste generator?

- Pollution prevention and waste minimization?

3. Does the EV Site Plan have the following objectives and statements of scope?

- A statement of pollution prevention scope and objectives developed and distributed to all project personnel?

- A statement of pollution prevention scope and objectives developed and distributed to all contractor personnel?

- A statement of pollution prevention scope and objectives developed and distributed to all safety and emergency response personnel?

- Specific numerical goals for pollution prevention for each project waste stream set and distributed or displayed to all project personnel?

- Specific numerical goals for pollution prevention for each project waste stream set and distributed or displayed to all contractor personnel?

- Specific numerical goals for pollution prevention for each project waste stream set and distributed or displayed to all safety and emergency response personnel?

Fig. 1. EV Project Phase Checklist. 
4. Have project managers or personnel initiated work and waste management plans for projects that are scheduled to start within 180 days or less from now?

- PP/WM incorporated in any of the project work/waste management pláss?

- A section on PP/WM incorporated in at least one of the project work and waste management plans?

- A section on PP/WM in all the project work and waste management plans?

- A section on PP/WM in all the project work and waste management plans? Each section discusses at least three techniques to reduce or prevent waste generation?

5. Do project managers or personnel have the following data relating to site operations and waste streams so that pollution prevention opportunities can be identified?

- Supply and distribution records (i.e., chemical inventories, chainsof-custody, and waste drum tracking information)?

- Maintenance records (i.e., inspection and preventive maintenance repair orders)?

- Supervision records [i.e., quality assurance (QA) audits, noncompliance, and personnel records]?

- Required permits and records (i.e., CAA, NPDES, and RCRA monitoring, RCRA accumulations facility inventories and manifests, CERCLA reportable quantity release, and sample waste analyses)?

- PP/WM Program documentation (i.e., all work/waste management plans for projects scheduled 180 days or less from now)?

- Design information (i.e., process flow diagrams and material balances)?

- Environmental information and reporting (i.e., sample waste analyses, RCRA/Tennessee Annual Report, EPA Biannual Report, and Pollution Prevention Act Tri-Report)?

- Raw material site information (i.e., material safety data sheets, contractor data logs, site operating procedures, and project schedules and milestones)?

Fig. 1 (continued) 
YES N $\quad$ NO

- Economic information (i.e., waste treatment, disposal, operating, maintenance and departmental and pollution prevention implementation costs)?

6. Have project managers or personnel had the PP/WM Program audited in the last 12 months?

Was the program audited in the following manner?

- A periodic schedule for audit of activities was made?

- The audit was performed by those who have direct responsibility for performing the activities being audited?

- The audit was performed by those who do not have direct responsibility for performing the activities being audited?

- The audit was reviewed by responsible management?

- Follow-up action was taken as a result of the audit?

7. Have project managers or personnel insisted on assessment of the waste streams to reduce or prevent waste generation?

Have the following project waste assessment elements been performed?

- Review of the PP/WM operations and waste management issues and targeted work sites that should be assessed?

- Development of flow diagrams and materials balances for each targeted work site?

- Identification of PP/WM opportunities and projects that address those opportunities?

- Evaluation and ranking of projects into a coordinated, long-range facility plan?

8. Do project managers or personnel have cost, schedule, and program contents specific to the PP/WM Program activities?

What kind of waste accounting is performed?

- Are operating cost records kept?

- Are treatment cost records kept?

- Are disposal cost records kept?

- Are maintenance cost records kept?

Fig 1 (continued) 
- Are life-cycle cost records kept?

- Are costs to implement pollution prevention activities kept?

- Are real-time cost savings since PP/WM plan implementations kept?

9. Have project managers or personnel evaluated the pollution prevention program to the numerical goal criteria in the last 12 months?

Are the following criteria used to evaluate the pollution prevention program?

- Number of numerical goals achieved?

- Number of cost reductions achieved?

- Number of noncompliances cited?

- Number of new technologies integrated?

- Number of noncompliances corrected?

10. Do project managers or personnel keep and organize records from pollution prevention activities for QA purposes?

Are the records from pollution prevention activities kept and organized in the following manner?

- Records furnish documentary evidence from all pollution prevention activities kept and organized?

- Records are well-organized and are easy to assess?

- Records are protected against damage, deteriorations, or loss?

- Requirements and responsibilities for record transmittal, distribution, retention, maintenance, and dispositions are established and documented?

11. Is technology information available for comparison from other sites for pollution prevention assessment?

- Parameters and results of a material or ER activity?

- Impact of the project of implementing a new technology?

- Remedial ER activities and materials currently used?

- Remedial ER activities and materials under consideration?

Fig. 1 (continued) 
12. If new technology information is available from other sites, does the facility manager or personnel have a timetable, cost, schedule, and possible implementation procedures on the new technology?

13. Do facility managers or personnel implement mechanisms for quality improvement in PP/WM to prevent noncompliance?

How often does management assess the PP/WM Program to ensure that it is adequate and effectively implemented?

a. Never.

b. No regular schedule for assessing the PP/WM Program; occasionally performed.

c. Regular schedule for assessing the PP/WM Program; performed every 2 years.

d. Regular schedule for assessing the PP/WM Program; performed every year.

e. Regular schedule for assessing the PP/WM Program; performed at least every 6 months.

14. Does the facility manager or personnel know who handles the waste generated?

a. It is not known who handles the waste.

b. The site waste management organization handles the waste.

c. The site waste management organization handles the waste and provides some data to meet reporting requirements.

d. The site waste management organization handles the waste and provides all data to meet reporting requirements.

Fig. 1 (continucd) 


\section{SECTION 2 EV PHASESPECIFIC QUESTION INFORMATION}

1. Does the ER PP/WM Program adequately address EV?

2. Does the EV phase of the ER PP/WM Program include specific quantitative goals for reducing the volume and toxicity of each waste stream?

3. If specific numerical goals are not included for each waste stream, is a strategy outlined to arrive at numerical goals?

4. Does the EV phase of the ER PP/WM Program include programmatic goals for the evaluation of new technologies to reduce waste generation?

5. Does the EV phase of the ER PP/WM Program contain a budget for its waste minimization program?

6. Has the organization developed baseline data for the generation of waste from EV-phase activities?

7. Does the ER PP/WM Program explain how PP/WM principles are incorporated into the EV phase?

8. Does the EV phase of the ER PP/WM Program require that waste assessments be conducted on the waste streams?

9. Does the EV phase of the ER PP/WM Program identify research and development projects related to $\mathrm{PP} / \mathrm{WM}$ ?

10. Does the EV phase of the ER PP/WM Program describe any planned technology-transfer aciivities?

11. Does the EV phase of the ER PP/WM Program provide a procedure for self-evaluation?

12. Does the EV phase of the ER PP/WM Program explain how design principles that minimize waste generation are incorporated into new construction and options that involve new or modified processies?

13. Does the EV phase of the ER PP/WM Program include a method of accounting for the cost of PP/WM activities?

14. Does the EV phase of the ER PP/WM Program address the need for, and methods of, waste segregation as it affects PP/WM?

15. Does the EV phase of the ER PP/WM Program address the need for, and methods of, housekeeping as it affects PP/WM?

Fig. 1 (continued) 
SECTION 3. WASTE STREAM INFORMATION

Facility/Site Description:

MATERIAL STREAM/CONTAMINANT/MEDIA

IDENTIFICATION SUMOMARY

Contaminant

Contaminant Group

\section{APPLICABLE CONTAMINANT MATERIAL DISPOSITION TECHNOLOGY SUMMARY}

Instructions:

Identify the material stream in the Summary of Contaminated Material Disposition Technology for Gaseous Diffusion Plants (Table 1, p. 16). Then identify any applicable existing or potential clean-up technologies.

Applicable Existing Technologies:

Applicable Potential Technologies:

Fig. 1 (continued) 


\section{TECHNOLOGY EVALUATION RATIONALE INCORPORATING PP/WM}

1. Have any applicable treatment technologies been identified that reduce

2. Can any primary waste streams be prevented or reduced at the source?

3. Have any applicable treatment technologies been identified that immobilize contaminants?

4. Can any primary waste stream(s) be reused or recycled after treatment?

5. Can any primary waste stream(s) be returned to the area of contamination after treatment?

6. Can any primary waste stream(s) be exchanged for reuse after treatment?

7. Can any secondary waste stream(s) be reused or recycled?

8. Can any secondary waste stream(s) be reused or recycled?

9. Can any secondary waste stream(s) be returned to the facility?

10. Can any secondary waste stream(s) be exchanged for reuse after treatment?

$\begin{array}{ll}\text { - Volume } & - \text { Toxicity } \\ \text { Radioactivity } & -\begin{array}{l}\text { Does Not } \\ \text { Apply }\end{array} \\ - \text { Yes } & - \text { No } \\ - \text { Yes } & - \text { No } \\ \text { Yes } & - \text { No } \\ \text { Yes } & - \text { No } \\ \text { Yes } & - \text { No } \\ \text { Yes } & - \text { No } \\ \text { Yes } & - \text { No } \\ \text { Yes } & - \text { No }\end{array}$

Fig. 1 (continucd) 
TECHNOLOGY EVALUATION RATIONALE INCORPORATING PP/WM

Technology Evaluation Rationale:

PP/WM Rationale:

Fig. 1 (continued) 


\section{WASTE STREAM INFORMATION}

Facility/Site Description: The K-333 Building Facility equipment is internally contaminated with radionuclides such as uranium that form volatile fluorides. This facility was utilized as part of the gaseous diffusion process for uranium enrichment.

\section{MATERIAL STREAM/CONTAMINANT/MEDIA IDENTIFICATION SUMMARY}

\begin{tabular}{lcc} 
Material Stream & $\begin{array}{c}\text { Contaminanc } \\
\text { Ferrous Metal }\end{array}$ & Uranium \\
\hline & & Solid Stainless Steel Metal \\
\hline
\end{tabular}

\section{APPLICABLE CONTAMINANT MATERIAL DISPOSITION TECHNOLOGY SUMMARY}

\section{Instructions:}

Identify the material stream in the Summary of Contaminated Material Disposition Technology for Gaseous Diffusion Plants (Table 1, p. 16). Then identify any applicable existing or potential clean-up technologies.

Applicable Existing Technologies: Recycle as is, remelt high-pressure water decontamination, standard cutting

Applicable Potential Technologies: (1) Melt and glass decontamination, (2) microwave heating, (3) induction heating, (4) ultra-high pressure water, (5) cryogenic pellet decontamination, (6) chemical decontamination, (7) electrochemical methods, and (8) gas-phase decontamination

Fig. 2. Example Waste Stream Information. 


\section{TECHNOLOGY EVALUATION RATIONALE INCORPORATING PP/WM}

1. Have any applicable treatment technologies been identified that reduce

2. Can any primary waste streams be prevented or reduced at the source?

3. Have any applicable treatment technologies been identified that immobilize contaminants?

4. Can any primary waste stream(s) be reused or recycled after treatment?

5. Can any primary waste stream(s) be returned to the area of contamination after treatment?

6. Can any primary waste stream(s) be exchanged for reuse after treatment?

7. Can any secondary waste stream(s) be reused or recycled?

8. Can any secondary waste stream(s) be reused or recycled?

9. Can any secondary waste stream(s) be returned to the facility?

10. Can any secondary waste stream(s) be exchanged for reuse after treatment?
$-\underline{X}$ Volume

Toxicity

Radioactivity

$\underline{X}$ Yes

$\underline{X}$ Yes

No

- Yes

X No

$\underline{X}$ Yes

No

- Yes

$\underline{X}$ No

$\underline{X}$ Yes

No

- Yes

$\underline{X}$ No

- Yes

$\underline{X}$ No

- Yes

$\underline{X}$ No

Fig. 2 (continued) 


\section{TECHNOLOGY EVALUATION RATIONALE INCORPORATING PP/WM}

\section{Technology Evaluation Rationale:}

The metal cannot be recycled for unrestricted use in its present form because of the lack of de minimus standards. The volume of metal involved in this decommissionine and decontamination effort is so large that surface burial as waste is not an acceptable solution. High-pressure water has been shown to be effective for surface contamination, but this technology produces a secondary large waste stream from the water used in this system.

When evaluating the applicable potential technologies, the volume of metal is so large that technology number 1 will not be adequate or cost effective. Technology numbers 2 and 3 are in the very early stages of development: therefore not adequate to be applied to this system. Technology numbers 4.5 and 6 exist and have been developed for decontamination. Consequently technology number 5 has slow kinetics, while technology numbers 4 and 6 generate large secondary waste streams. Technology number 7 has a wide application and needs to be further tested for use in decontaminating a wide variety of metals. Technology number 8 is preferred for this material stream. This technology is cost-effective decontamination for intact gaseous diffusion process/separation facilities equipment contaminated internally with uranium radionuclides that form volatile fluorides and oxvfluorides. This decontamination technology is effective with the materials and geometro of the following:

. axial compressors.

e centrifugal compressors.

e converters.

e miscellaneous small converter parts.

e external gas-cooler parts.

. tube sheets.

a control and block valves, and

e pipe sections.

Effective decontamination of this equipment before (and possibly without) disassembly would alleviate criticality concerns. minimize the spread of contamination. reduce worker exposure to hazardous and radioactive materials, and reduce costs,

\section{PP/WM Rationale:}

Potentially all of the radionuclides in the gaseous diffusion process can be volatilized as fluorides. By using gas-phase decontamination, liquid wastes would be eliminated, solid wastes would be reduced by over $90 \%$, and air emissions would be reduced to a minor problem. Wastes would be prevented at the source.

Fig. 2 (continucd) 
Table 1. Summary of Contaminated Material Disposition Technology for Gascous Diffusion Plants

\begin{tabular}{|c|c|c|}
\hline Material stream & Existing technology & $\begin{array}{l}\text { Technologies with potential } \\
\text { for development }\end{array}$ \\
\hline Concrete rubble & Shallow land burial & $\begin{array}{l}\text { Washing of rubble } \\
\text { Volume reduction }\end{array}$ \\
\hline Clean concrete & $\begin{array}{l}\text { Sampling and chemical } \\
\text { analysis }\end{array}$ & $\begin{array}{l}\text { Analysis techniques } \\
\text { to prove cleanliness }\end{array}$ \\
\hline $\begin{array}{l}\text { Concrete contaminated } \\
\text { with radionuclides }\end{array}$ & $\begin{array}{l}\text { High-pressure water } \\
\text { decontamination } \\
\text { Carbon dioxide } \\
\text { decontamination }\end{array}$ & $\begin{array}{l}\text { Microwave system } \\
\text { Plasma system } \\
\text { Chemical system }\end{array}$ \\
\hline Ferrous metals & $\begin{array}{l}\text { Recycling as is } \\
\text { Remelting } \\
\text { High-pressure water } \\
\text { decontamination } \\
\text { Standard cutting }\end{array}$ & $\begin{array}{l}\text { Melt and glass } \\
\text { decontamination } \\
\text { Microwave heating } \\
\text { Induction heating } \\
\text { Gas-phase } \\
\text { decontamination } \\
\text { Ultrahigh-pressure water } \\
\text { decontamination } \\
\text { Cryogenic pellet } \\
\text { decontamination } \\
\text { Chemical decontamination } \\
\text { Electrochemical methods }\end{array}$ \\
\hline Nonferrous metals & $\begin{array}{l}\text { Recycling as is } \\
\text { Refining } \\
\text { Remelting } \\
\text { Chemical and electrochemical } \\
\text { processing } \\
\text { Testing } \\
\text { Standard cutting }\end{array}$ & $\begin{array}{l}\text { Gas-phase } \\
\text { decontamination } \\
\text { Ultrahigh-pressure water } \\
\text { decontamination } \\
\text { Cryogenic pellet } \\
\text { decontamination } \\
\text { Chemical decontamination } \\
\text { Electrochemical methods }\end{array}$ \\
\hline Protective clothing & Job planning & Reuse \\
\hline $\begin{array}{l}\text { Wood and combustible } \\
\text { materials }\end{array}$ & & $\begin{array}{l}\text { Bulk decontamination } \\
\text { methods }\end{array}$ \\
\hline Asbestos & $\begin{array}{l}\text { Automatic cutters and knives } \\
\text { Wetting agent use } \\
\text { Vacuum system }\end{array}$ & Water jet decontamination \\
\hline PCBs-equipment & Solvent flushing/washing & \\
\hline $\begin{array}{l}\text { PCBs } \\
\text { hydrocarbon } \\
\text { liquids }\end{array}$ & $\begin{array}{l}\text { Chemical treatment } \\
\text { Incineration }\end{array}$ & \\
\hline
\end{tabular}


Table 1 (continued)

\begin{tabular}{|c|c|c|}
\hline Material stream & Existing technology & $\begin{array}{c}\text { Technologies with potential } \\
\text { for development }\end{array}$ \\
\hline PCBs-soil/sludge & $\begin{array}{l}\text { Solidification } \\
\text { Bioremediation } \\
\text { Soil washing/extraction } \\
\text { Transportable thermal } \\
\text { treatment } \\
\text { Vitrification thermal treatment } \\
\text { Vitrification thermal } \\
\text { separation }\end{array}$ & \\
\hline PCBs-water & $\begin{array}{l}\text { Chemical dechlorination } \\
\text { Bioremediation } \\
\text { Physical separation/carbon } \\
\text { adsorption }\end{array}$ & \\
\hline PCBs-buildings & $\begin{array}{l}\text { Concrete shaving/shot blasting/ } \\
\text { scarifying } \\
\text { Paint stripping/high pressure } \\
\text { water decontamination } \\
\text { Surface chemical treatment } \\
\text { Solvent/coating use }\end{array}$ & \\
\hline \multicolumn{3}{|l|}{ Acids } \\
\hline Contaminated waters & Filtration & Fluid recycling \\
\hline Freon & Solvent cleaning & $\begin{array}{l}\text { High-pressure cleanup } \\
\text { equipment }\end{array}$ \\
\hline Glass & $\begin{array}{l}\text { Glass decontamination } \\
\text { Volume reduction }\end{array}$ & \\
\hline Mercury at $\mathrm{Y}-12$ & Storage & \\
\hline Oils and organics & & $\begin{array}{l}\text { Biological methods } \\
\text { Bulk decontamination } \\
\text { methods } \\
\text { Dry heat system }\end{array}$ \\
\hline Enriched uranium & $\begin{array}{l}\text { Recycling } \\
\text { Reuse }\end{array}$ & \\
\hline Transite siding & Automatic cutters and knives & \\
\hline \multicolumn{3}{|l|}{ Returned sources } \\
\hline Nickel & Storage & Refining \\
\hline Copper wire & Storage & $\begin{array}{l}\text { Contamination detection } \\
\text { equipment }\end{array}$ \\
\hline Assorted metals & Storage & $\begin{array}{l}\text { High-speed segregation } \\
\text { techniques } \\
\text { Volume reduction }\end{array}$ \\
\hline
\end{tabular}


Table 1 (continued)

\begin{tabular}{|c|c|c|}
\hline Material stream & Existing technology & $\begin{array}{l}\text { Technologies with potential } \\
\text { for development }\end{array}$ \\
\hline Lead & $\begin{array}{l}\text { High-pressure water } \\
\text { decontamination } \\
\text { Machining } \\
\text { Decontamination of coatings } \\
\text { Storage }\end{array}$ & Melt refining \\
\hline Mixed waste & $\begin{array}{l}\text { Thermal destruction } \\
\text { of organics } \\
\text { Chemical destruction } \\
\text { of organics } \\
\text { Grouting } \\
\text { Filtering } \\
\text { Evaporation } \\
\text { Ion exchange } \\
\text { Storage }\end{array}$ & $\begin{array}{l}\text { Organic destruction } \\
\text { Ion exchange } \\
\text { Incineration } \\
\text { Vitrification } \\
\text { Separation technologies }\end{array}$ \\
\hline Sludges & $\begin{array}{l}\text { Cement } \\
\text { Evaporation } \\
\text { Vitrification } \\
\text { Storage }\end{array}$ & $\begin{array}{l}\text { In-tank evaporation } \\
\text { Stabilization technology } \\
\text { Sampling } \\
\text { Volume efficiency } \\
\text { of concrete } \\
\text { Solidification } \\
\text { Vitrification }\end{array}$ \\
\hline Contaminated soil & $\begin{array}{l}\text { Soil washing } \\
\text { Packaging on ground } \\
\text { Freeze grinding } \\
\text { Reduction of TRU-LLW } \\
\text { Air cleaning } \\
\text { Soil compaction } \\
\text { Leaching } \\
\text { Biotreatment }\end{array}$ & $\begin{array}{l}\text { Soil compaction } \\
\text { Biotreatment } \\
\text { Leaching } \\
\text { Soil washing }\end{array}$ \\
\hline TRU waste & Electropolishing & Nitric acid electrolytes \\
\hline
\end{tabular}




\section{BIBLIOGRAPHY}

Energy Systems (Martin Marietta Energy Systems, Inc.). 1993. Oak Ridge K-25 Site Technology Logic Diagram, Vol. 1: Technology Evaluation. K-2073, Oak Ridge K-25 Site, Oak Ridge, Tennessee, February.

Energy Systems. 1993. Oak Ridge K-25 Site Technology Logic Diagram, Vol. 2: Technology Logic Diagrams. K-2073, Oak Ridge K-25 Site, Oak Ridge, Tennessee, February.

Energy Systems. 1993. Oak Ridge K.25 Site Technology Logic Diagram, Vol. 3, Part A: Characterization, Decontamination, and Dismantlement. K-2073, Oak Ridge K-25 Site, Oak Ridge, Tennessee, February.

Energy Systems. 1993. Oak Ridge K-25 Site Technology Logic Diagram, Vol. 3, Part B: Remedial Action, Robotics/Automation, and Waste Management. K-2073, Oak Ridge K-25 Site, Oak Ridge, Tennessee, February.

Energy Systems. 1993. Decontamination and Decommissioning Technology Assessment. DOE/OR-1051, Oak Ridge K-25 Site, Technical Division, Oak Ridge Tennessee, March. 


\section{DISTRIBUTION}

1. D. T. Bell

2. J. M. Cash

3. J. S. Colley

4. R. B. Cook

5. S. L. Cross

6. M. F. P. DeLozier

7. C. D. Goins

8. P. J. Halsey

9. T. C. Houk

10. S. H. Howell

11. R. K. Kubbe

12-13. A. K. Lee/DOE-OSTI

14. S. M. Leone

15-18. D. M. Matteo

19-20. P. T. Owen

21. G. A. Person

22. B. E. Phifer, Jr.

23. A. S. Quist

24. G. E. Rymer

25. P. C. Stumb

26. J. S. Suffern

27. A. E. Walzer

28. D. R. Watkins

29. R. K. White

30. Central Research Library

31-35. ER Document Management Center

36. ORNL Laboratory Records

37-38. R. L. Nace, Branch Chief, Nonenrichment Facilities, Oak Ridge Program Division, Office of Eastern Area Programs, Office of Environmental Restoration, EM-423, Trevion 2, U.S. Department of Energy, Washington, DC 20585

39. R. C. Sleeman, DOE Oak Ridge Fleld Office, P.O. Box 2001, Oak Ridge, TN 37831-8541

40. D. W. Swindle, Radian Corporation, 120 South Jefferson Circle, Oak Ridge, TN 37830

41-42. H. M. Thron, Chief, Enrichment Facilities, Oak Ridge Program Division, Office of Eastern Area Programs, Office of Environmental Restoration, EM-423, Trevion 2, U.S. Department of Energy, Washington, DC 20585

43. Office of Scientific and Technical Information, P.O. Box 62, Oak Ridge, TN 37831 

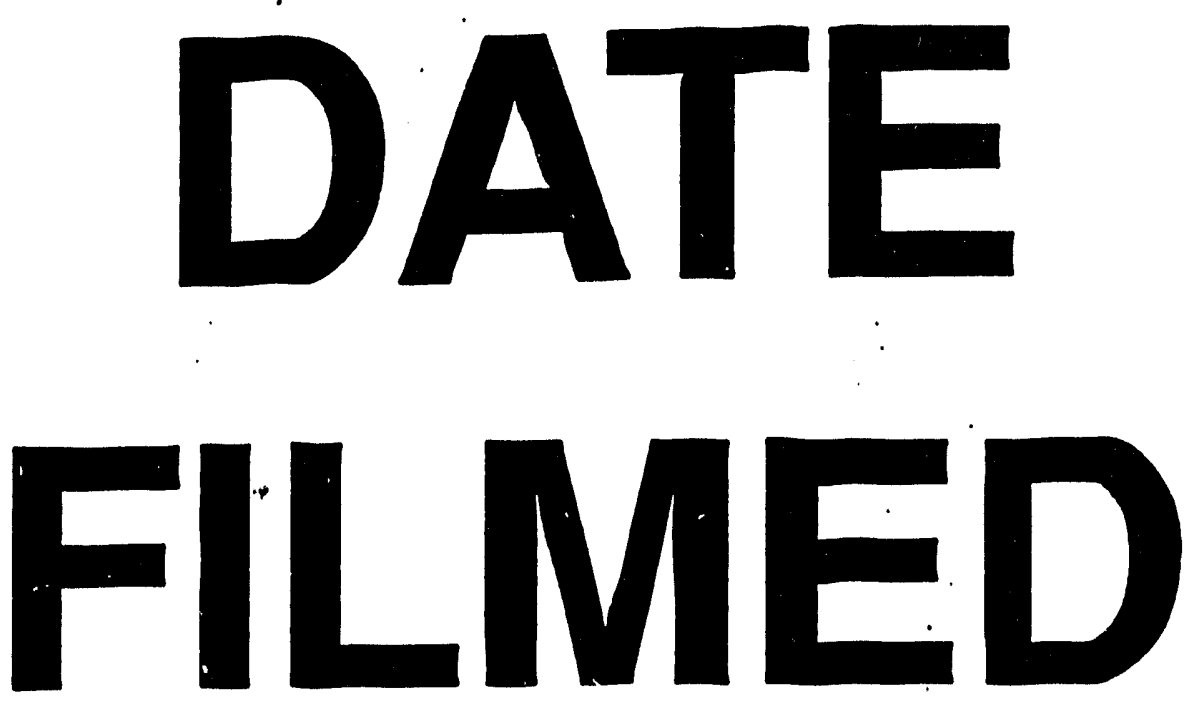

$12 / 6 / 93$
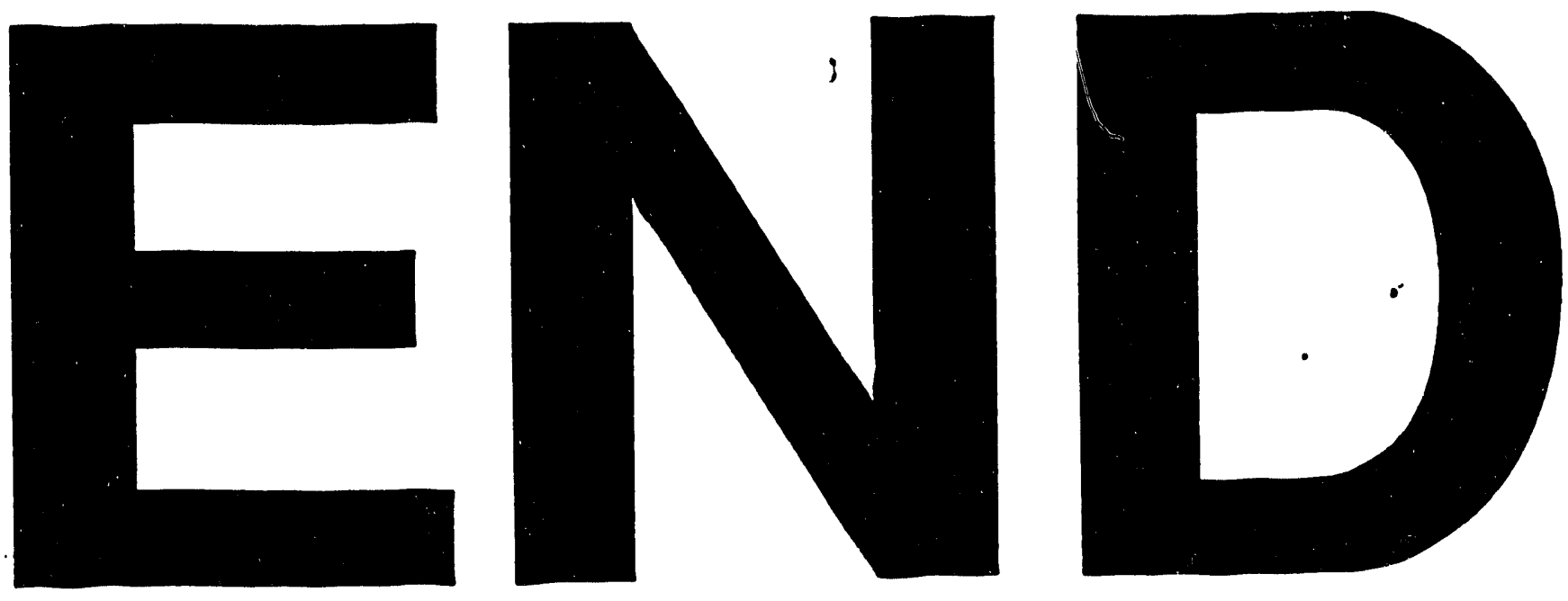
